\title{
VELADAS LITERARIO-MUSICALES Y MANIFESTACIONES PÚBLICAS EN LA CONSTRUCCIÓN DEL PRIMERO DE MAYO EN TUCUMÁN (ARGENTINA), 1897-1925
}

\author{
LITERARY-MUSICAL EVENINGS AND PUBLIC \\ MANIFESTATIONS IN THE CONSTRUCTION OF MAY IN \\ TUCUMÁN (ARGENTINA), 1897-1925
}

Vanessa Teitelbaum*

\begin{abstract}
Resumen: En este artículo me propongo analizar las veladas y manifestaciones del $1^{\circ}$ de Mayo en Tucumán, provincia del noroeste argentino, temática central en los estudios del mundo del trabajo pero que hasta ahora no ha sido explorada para el periodo y el espacio elegido. El corte temporal inicia, aproximadamente a finales de la década de 1890 y comienzos del novecientos --cuando se recordó por primera vez el $1^{\circ}$ de Mayo en la provincia-- y concluye hacia mediados de los años 1920, con la intervención del Estado en dicha conmemoración. Desde una perspectiva de historia social, se analizarán documentos escritos y visuales contenidos en la prensa periódica provincial y los diarios obreros, junto con testimonios de militantes y dirigentes del periodo para indagar la construcción de este ritual obrero, así como los significados en pugna que se desplegaron torno a esta efeméride, entendida como la principal conmemoración obrera y percibida como una arena de disputa entre las distintas fuerzas del movimiento obrero, los partidos políticos y finalmente el Estado.
\end{abstract}

Palabras-clave: $1^{\circ}$ de mayo, socialistas, anarquistas.

\footnotetext{
* Doctora en Historia por El Colegio de México. Investigadora Adjunta del Conicet y
} 
Docente Auxiliar de Historia social y política argentina, Facultad de Filosofía y Letras, UNT. E-mail: vteitel@yahoo.com

\begin{abstract}
In his paper I will analyze the evenings and demonstrations of May 1 in Tucumán, a province in northwestern Argentina, central theme in studies of the world of work but so far has not been explored for the period and the space chosen. The temporary cut starts, about the end of the 1890s and beginning of the twentieth century - when it was recalled for the first time on 1 May in the province - and concludes in the mid-1920s, with the intervention of the State in this commemoration. From the perspective of social history, written documents and visual content on periodic provincial daily press and the workers, along with testimonials from members and leaders of the period to investigate the emergence, formation and some of the meanings that were deployed around will analyze this event, defined as the main working and commemoration perceived as an arena of contention between the various forces of the labor movement, political parties and ultimately the state.
\end{abstract}

Keywords: May 1, socialists, anarchists.

\title{
INTRODUCCIÓN
}

En este artículo me propongo analizar las veladas y las manifestaciones del $1^{\circ}$ de Mayo en Tucumán en un periodo que inicia, aproximadamente, entre finales de la década de 1890 y comienzos del novecientos --cuando se recordó por primera vez esta efeméride en la provincia-- y concluye hacia mediados de los años 1920, con la intervención del Estado en dicha conmemoración. Sin ánimo de agotar el tema con estas páginas pero sí mostrar aspectos novedosos, me interesa avanzar en aspectos relacionados con la construcción de este ritual obrero, indagando algunos significados que se desplegaron en torno a esta fecha, entendida como la principal conmemoración obrera y, por lo mismo, percibida como una arena de disputa entre las distintas fuerzas del movimiento obrero, los partidos políticos y finalmente el Estado. ${ }^{1}$

Desde una perspectiva de historia social, abierta a su vez a los fenómenos culturales y políticos, y empleando, básicamente, metodología cualitativa, analizaremos un conjunto de fuentes, principalmente documentos periodísticos, tanto escritos como visuales, difundidos a través de las páginas de la prensa periódica provincial y los diarios obreros. Así, para la etapa que abarca desde el año 1897 a 1925 examinamos el principal diario de Tucumán durante la época estudiada: El Orden, fundado en 1883, en plena época roquista, ${ }^{2}$ que durante los primeros años del siglo $\mathrm{XX}$ transitó desde el apoyo al gobierno provincial de Lucas Córdoba y a su partido oficial "Unión Provincial" que respaldaba al gobierno del presidente Roca a su transformación hacia 1902-1903 en un órgano de expresión opositor, portavoz 
del bloque político integrado por industriales azucareros adversos a la política de L. Córdoba, gobernador de Tucumán entre 1895 y 1898 y entre 1901 y 1904. ${ }^{3}$ Como portavoz de esta nueva corriente política, El Orden, recrudeció sus críticas al "luquismo", inscribiéndose abiertamente en el sector opositor al roquismo.

Para algunos años, también, contamos con la información obtenida de una publicación sobre la cual hasta ahora no se tenía ninguna noticia, de tendencia liberal y presentada como un semanario que defendía la causa de los trabajadores, denominada sugestivamente La Estrella del Norte. Semanario liberal y defensor de la clase trabajadora.

Los años 1896-1907 fueron cubiertos, además, por la prensa obrera, en particular por el semanario y posteriormente diario que se posicionó como el órgano oficial del partido Socialista en Argentina, La Vanguardia. A su vez, La Protesta Humana, uno de los principales medios de expresión del anarquismo en el país nos sirvió para completar nuestra revisión de la etapa comprendida entre 1898-1908. Portavoz de la corriente libertaria en Tucumán y sin duda una fuente de suma importancia para esta investigación fue Germinal, publicación editada como un número único por la Federación Obrera Local Tucumana para conmemorar el $1^{\circ}$ de mayo de $1908 .{ }^{5}$ Estos materiales se complementaron con la lectura de los testimonios de militantes y dirigentes del periodo que formaban parte de las corrientes de izquierda en el mundo del trabajo. En especial, revisamos los escritos del socialista Nicolás Repetto, quien dejó sus impresiones sobre la gira que realizó por el norte argentino al despuntar el siglo XX y los comentarios que hacia mediados y finales del novecientos realizó el líder del sindicalismo Luis Lotito. No está demás apuntar que algunos testimonios de Repetto sobre el asociacionismo obrero en Tucumán aparecieron primero en La Vanguardia, mientras que los escritos de Lotito fueron publicitados entre finales de 1907 y abril de 1908 en una serie compuesta por seis artículos difundidos en $L a$ Acción Socialista, periódico que representaba a la corriente sindicalista revolucionaria, recientemente separada del Partido Socialista. ${ }^{6}$

Entendida como la principal conmemoración obrera, el $1^{\circ}$ de Mayo constituye una temática medular en los del mundo del trabajo. Sin embargo, hasta ahora no ha recibido ninguna atención por parte de la historiografía sobre Tucumán para la época bajo estudio. En contraste, contamos con valiosas investigaciones centradas en otras regiones del país y del extranjero. Por ejemplo, una revisión de la literatura sobre el tema reveló que las distintas concepciones del $1^{\circ}$ de Mayo formuladas, en especial, por socialistas, anarquistas y más tarde comunistas, así como la ocupación del espacio público por parte de los trabajadores que configuraron verdaderos rituales de manifestación fueron algunas de las cuestiones sobre las cuales ahondó la historiografía para la capital del país, la ciudad de Buenos Aires, y otros importantes núcleos urbanos tanto de Argentina como de otras latitudes de 
América Latina y de Europa. ${ }^{7} \mathrm{Al}$ no contar con este tipo de estudios para espacios locales como el tucumano, este trabajo -estimo-- podría ser un aporte para reconstruir y explicar las conmemoraciones de los trabajadores $\mathrm{y}$, en especial para historiar el $1^{\circ}$ de Mayo, en un periodo clave, caracterizado por la formación del movimiento obrero en numerosos escenarios.

A su vez, investigar las manifestaciones que evocaban esta efeméride nodal del calendario obrero podría alentar una mayor comprensión en torno a los procesos de producción de memorias que se actualizan, adquieren nuevos significados y reflejan las disputas sociales a lo largo de la historia. De esta manera, la temática abordada en este artículo permitiría situar los procesos de lucha de los trabajadores, repensar el papel del Estado y reflexionar sobre el peso de las distintas fuerzas políticas que disputan los sentidos y los atributos de las conmemoraciones incluso hasta el día de hoy. ${ }^{8}$

Finalmente, las problemáticas planteadas en esta contribución se vinculan con debates historiográficos actuales, como los referidos a la participación de los trabajadores en la vida pública mediante un tejido asociacionista, las manifestaciones de protestas y de resistencias populares y la construcción de rituales y símbolos, con lo cual sus resultados podrán ser contrastados con otras experiencias nacionales, regionales y locales, en especial de los ámbitos argentinos y latinoamericano. ${ }^{9}$

\section{LOS ORÍGENES DEL $1^{\circ}$ DE MAYO EN TUCUMÁN}

El $1^{\circ}$ de Mayo constituía una efeméride medular de la cultura obrera que se conmemoraba en diversas partes del mundo desde finales de la década de $1880 .{ }^{10}$ Una lectura de las fuentes permite proponer que en Tucumán esta fecha se recordó por primera vez a finales del siglo XIX, ${ }^{11}$ en consonancia con los lineamientos establecidos por el partido Socialista en Argentina. ${ }^{12}$ En una tónica semejante a lo que sucedía en otras provincias del país, el Primero de Mayo involucraba dos momentos, estrechamente vinculados entre si, la manifestación de los trabajadores los lugares públicos de la ciudad, como calles y plazas, y las veladas que se celebraban en el local de los centros obreros. En ambos momentos los oradores eran, mayoritariamente, líderes obreros y dirigentes socialistas locales o enviados por el Comité Ejecutivo del partido Socialista. De acuerdo con el examen de las fuentes podemos trazar la siguiente pintura. Por lo general, los trabajadores recorrían organizados en columnas las calles y las plazas de la urbe, llevando las insignias y los símbolos que caracterizaban al movimiento obrero, como la bandera roja. En su marcha, iban acompañados por bandas de música que ejecutaban himnos revolucionarios. ${ }^{13}$ Tanto en esas movilizaciones como en las reuniones que tenían lugar en los locales obreros, los dirigentes socialistas pronunciaban discursos que insistían en la necesidad de luchar para obtener mejoras laborales, tales como la jornada de 8 horas, y subrayaban la importancia de participar en las elecciones, para lo cual era prioritario que los trabajadores 
extranjeros se naturalizaran. ${ }^{14}$

A modo ilustrativo, podemos mencionar la reunión del primero de Mayo de 1902, cuando el Centro Cosmopolita de Trabajadores, uno de los principales centros de trabajadores de la época liderado por corrientes del izquierda en el mundo del trabajo como el anarquismo y principalmente el socialismo, puso en marcha una velada musical compuesta por discursos que explicaban la historia del $1^{\circ}$ de mayo, abundaban en los reclamos característicos del socialismo sobre la denominada "política criolla" y proponían revertir la adjudicada "ignorancia de los trabajadores" a través de la organización de un partido de clase. ${ }^{15}$ Interesa anotar que varios de estos tópicos fueron recuperados después por Adrián Patroni, propagandista obrero proveniente del Litoral quien a los pocos días de esta velada llegó a la provincia proveniente de Buenos Aires y como parte de sus trabajos de propaganda dictó varias conferencias sobre aspectos relacionados con el socialismo, la democracia y la organización de los obreros. Tiene sentido proponer que la visita de renombrados dirigentes socialistas, tales como Adrián Patroni, ampliamente conocido en Tucumán por su papel de liderazgo en la huelga de los peones y jornaleros azucareros de 1904 --primer gran conflicto obrero en la provincia-- podían favorecer el interés de los trabajadores por asistir a las conferencias y participar de las movilizaciones del Primero de Mayo. Por otra parte, es factible sugerir que la conmemoración del $1^{\circ}$ de mayo fue percibida como una práctica esencial para fortalecer las relaciones asociativas, difundir la propaganda obrera y fomentar las ideas de lucha gremial y política de los trabajadores. De acuerdo con esos fines, la conmemoración del $1^{\circ}$ de mayo fue encabezada por los socialistas que se posicionaron como actores fundamentales en la organización del mundo del trabajo en Tucumán durante el periodo analizado en estas páginas.

Otra cuestión que me interesa destacar es la presencia de mujeres en estas conmemoraciones, tal como se reveló, por ejemplo, en la velada de mayo de 1904 desarrollada en la sede del Centro Cosmopolita de Trabajadores que contó con la participación de la Unión Gremial Femenina, organización recientemente formada al influjo del socialismo e integrada por trabajadoras de distintos gremios, principalmente por costureras de registro, cigarreras y más tarde alpargateras. ${ }^{16}$

Evidencia de la intervención de mujeres en las manifestaciones del Primero de Mayo fue también la velada literario-musical que se desarrolló el sábado 6 de mayo del año siguiente en las instalaciones del Centro Socialista, ámbito que con funciones semejantes pero con una afiliación más explícita al partido Socialista se constituyó en San Miguel de Tucumán a mediados de 1904. En dicha celebración, Rosa Rodríguez, una militante, afirmaba:

(...) El $1^{\circ}$ de mayo nos invita a todos sin distinción de sexos a entrar en una nueva vida, que el socialismo enseña que 
es de trabajo y paz, de luz y de verdad y de regeneración social.

(...) Cábeme la satisfacción en este instante en que los corazones proletarios laten al impulso del bello ideal socialista, de hacer entrega de la bandera a este centro, confeccionada por mis compañeras entusiastas, siendo mis votos por que la hagáis flamear siempre inmaculada, hasta que logréis implantarla victoriosa en la alta cumbre desde donde la nueva humanidad contemple satisfecha la obra redentora del socialismo. ¡Viva el $1^{\circ}$ de mayo! ${ }^{17}$

Sus palabras, recogidas en las páginas de La Estrella del Norte. Semanario liberal y defensor de la clase trabajadora, publicación sobre la cual hasta ahora no se tenía ninguna noticia, revela la participación de las mujeres durante el periodo formativo del movimiento obrero en la provincia, tema muy poco transitado por la historiografía local. Al respecto, interesa añadir que la conmemoración del $1^{\mathrm{o}}$ de mayo de ese año se completó con manifestación de los trabajadores en los espacios públicos. En dicha reunión fue significativa la intervención de las trabajadoras, un número estimado en doscientas obreras según cifras proporcionadas por la prensa, que participaron a través de la Sección Femenina de la Unión General de Trabajadores (UGT), organización de segundo grado dominada por el socialismo y que tuvo su presencia en Tucumán, especialmente en el departamento de Cruz Alta, principal zona azucarera de la provincia. ${ }^{18}$

Otra fuente particularmente valiosa para el estudio de la conmemoración del $1^{\circ}$ de Mayo en Tucumán durante la primera década del siglo XX y uno de los muy escasos documentos sobre el anarquismo en la provincia para dicho periodo es el número único titulado Germinal que editó en 1908 la Federación Obrera Local Tucumana (FOL), formada en 1906 y que reunía a las agrupaciones de obreros urbanos de la ciudad de San Miguel de Tucumán. Allí, pueden leerse las concepciones y definiciones de los militantes anarquistas acerca de esta efeméride obrera, entendida como una jornada de protesta y de lucha, absolutamente opuesta a la noción de fiesta que --se entendía-pretendían asignarle al Primero de Mayo los socialistas. Una muestra en ese sentido se plasmó en las palabras plasmadas en el artículo firmado con el seudónimo PVP, que probablemente pertenecían --tal como sugería Santiago Bilbao en un estudio sobre el tema-- al dirigente anarquista Tomás Delgado, quien hacia 1907 se desempeñaba como uno de los principales activistas de la Federación Obrera Local. ${ }^{19}$

El primero de Mayo no es un día de fiesta para la clase desposeída, aunque así lo afirmen los socialistas, los que ofician de rebañizadores. El primero de mayo es 
día de recordaciones y de protestas, es un día en que los trabajadores conscientes se dedican a gestar la vida libre que alborea ya y que será una realidad mañana; en ese día, se compara la condición maleva de la burguesía patria y de la mansedumbre que opone el trabajador de este suelo en contra de ese avanzar de la dictadura y de la opresión gubernamental aliada a la explotación capitalista. Y por eso no iremos a las plazas públicas en procesión apacible y decorativa, quede ello para los socialistas, los arlequines y los amantes del orden estatal. Nosotros los anarquistas no debemos servir de distracciones y solaz para la clase opresora y rapaz, saldremos a la calle no para cantar nuestros dolores en estrofas sentimentales sino para hacer algo más que todo eso, para exigir la parte que nos corresponde en este banquete social al que aportamos todo el caudal de nuestras energías y todo lo que se expone en la mesa. Y decimos para exigir la parte que nos corresponde porque no somos --como lo creen toda la turba de idiotas que defienden el capital-- los que queremos acapararlo todo en provecho exclusivo nuestro, sino únicamente que cada uno trabaje y produzcan para que puedan comer, ayudándonos a complementar la vida y a embellecerla, viviendo en la comunidad libre de los hombres libres. Este es el verdadero significado del Primero de Mayo, día de recordación y de afianzamiento de fe. ${ }^{20}$

Sin embargo, una lectura de las fuentes reveló que los socialistas de la época no subrayaban claramente el carácter festivo del $1^{\circ}$ de Mayo sino que este fue un sentido construido de forma gradual en el tiempo. A nuestro entender, las diferencias en los discursos sobre el Primero de Mayo se reflejaron en el tono más combativo que caracterizaba al ideario anarquista en contraste con el cariz más conciliador del socialismo, aunque ambos movimientos coincidían en destacar el significado de protesta del $1^{\circ}$ de mayo. Ejemplo de lo anterior fue el artículo, difundido también en Germinal, que escribió Horacio Stabile, dirigente afín al socialismo que al despuntar el novecientos integró la Comisión Directiva del Centro Cosmopolita de Trabajadores y a los pocos años ocupó el cargo de Secretario de Actas en la sociedad gremial Obreros Sastres. ${ }^{21}$ En dicha nota que llevaba por título "Mi voz al esclavo" Stabile afirmaba que "el primero de mayo no es una fiesta para los asalariados sino un día de protesta contra nuestros explotadores, un día de protesta contra todos los poderes constituidos como ser el estado pontificio, ese estado que representa la religión católica, apostólica, la cual hace un siglo que domina el mundo.” Además de la Iglesia católica, el dirigente de los sastres denunciaba los otros dos poderes que oprimían al proletariado, los cuales se entendía 
eran los gobiernos y el capital, para finalmente asegurar que el $1^{\circ}$ de mayo simbolizaba

la protesta unánime de todos los hombres de trabajo contra esos poderes sin fundamento, porque no tienen razón de ser, basado en la forma de esclavitud del presente régimen social, que viene a ser una contradicción con las leyes naturales de la inercia, de la gravedad que rigen los destinos del universo. ${ }^{22}$

Por esta vía, Stabile mostraba lo que probablemente era una postura más interesada en encontrar los puntos de contacto entre el socialismo y el anarquismo con relación al Primero de Mayo. No obstante estas coincidencias, tampoco debemos desconocer las divisiones y las tensiones que atravesaron al movimiento obrero en la época, reflejadas por lo general en la pugna entre anarquistas y socialistas. Dichos enfrentamientos se plasmaron, a su vez, en la prensa que mayoritariamente se pronunció en contra de las acciones del anarquismo, tendencia definida en términos de violencia y peligrosidad. ${ }^{23}$ Por ejemplo, en los relatos de $\mathrm{El}$ Orden sobre las manifestaciones del $1^{\circ}$ de Mayo podemos encontrar relatos salpicados por veladas referencias al anarquismo, movimiento al cual se le imputaba conductas desordenadas y violentas y, en contraposición, se comentaban las expresiones socialistas, consideradas como muestras de civilidad y orden de los obreros. Tal fue el caso de la descripción sobre la movilización del $1^{\circ}$ de mayo de 1906, reunión conducida por el dirigente obrero Adrián Patroni y que según el testimonio de la prensa local se extendía por seis cuadras y había demostrado un comportamiento sumamente correcto, al conducirse los trabajadores con "el mayor orden y compostura, sin el menor grito subversivo o irrespetuoso". Este último comentario probablemente traslucía una referencia al anarquismo. En una tónica semejante podemos interpretar la narración del diario El Orden sobre el $1^{\circ}$ de Mayo en 1909, en especial cuando aseguraba que "los obreros de Tucumán celebraron de una manera digna y culta la tradicional fecha, y el estandarte rojo se paseó por nuestras calles, no como símbolo de odio y de discordia sino de paz y de labor". ${ }^{24}$

Para cerrar este apartado, resulta indispensable añadir que la organización de los trabajadores en Tucumán durante el periodo analizado, en especial en los años comprendidos aproximadamente entre 1897 y 1910, no solo fue disputada por anarquistas y socialistas, quienes particularmente encabezaron las expresiones asociativas obreras en la provincia en la época, sino también por católicos, grupos con fuerte arraigo local y que fueron los principales contendientes del socialismo en el mundo del trabajo tucumano en esa etapa. 


\section{PROPAGANDA Y MANIFESTACIONES OBRERAS EN LA DÉCADA DE 1910}

Durante la segunda década del siglo XX las manifestaciones del $1^{\circ}$ de Mayo involucraron a un número mayor de participantes y reflejaron la creciente complejidad del movimiento obrero. Así, en 1914, alentados por el avance electoral del partido Socialista en la capital del país, los militantes y dirigentes socialistas en Tucumán reforzaron sus esfuerzos en la preparación de los actos del $1^{\circ}$ de Mayo, definida como la "fecha del proletariado internacional". Entre los festejos estaba prevista la realización de una velada que incluía la conferencia del destacado dirigente socialista Gregorio R. Pinto y una función cinematográfica sobre asuntos socialistas. Además, se programaba un acto central en el principal paseo público de la ciudad, la plaza Independencia, en donde hablaría el delegado enviado por el Comité Nacional del partido Socialista, el Dr. Mario Bravo. Recientemente reelecto como diputado nacional, Bravo constituía sin duda una figura de renombre en el socialismo argentino y su atractivo era aún mayor en la provincia debido a su origen tucumano. Probablemente por esto la convocatoria alcanzó una notable recepción entre los trabajadores que se dieron cita para escuchar la conferencia político-social del "distinguido comprovinciano". ${ }^{25}$

El numeroso público reunido y el entusiasmo que generó el acto del $1^{\circ}$ de Mayo entonces fueron capturados por una fotografía que a pesar de su poca nitidez constituye un testimonio sumamente valioso para el estudio de estos temas, además de la primera imagen localizada sobre el $1^{\circ}$ de Mayo en Tucumán (Figura 1). 
Figura 1

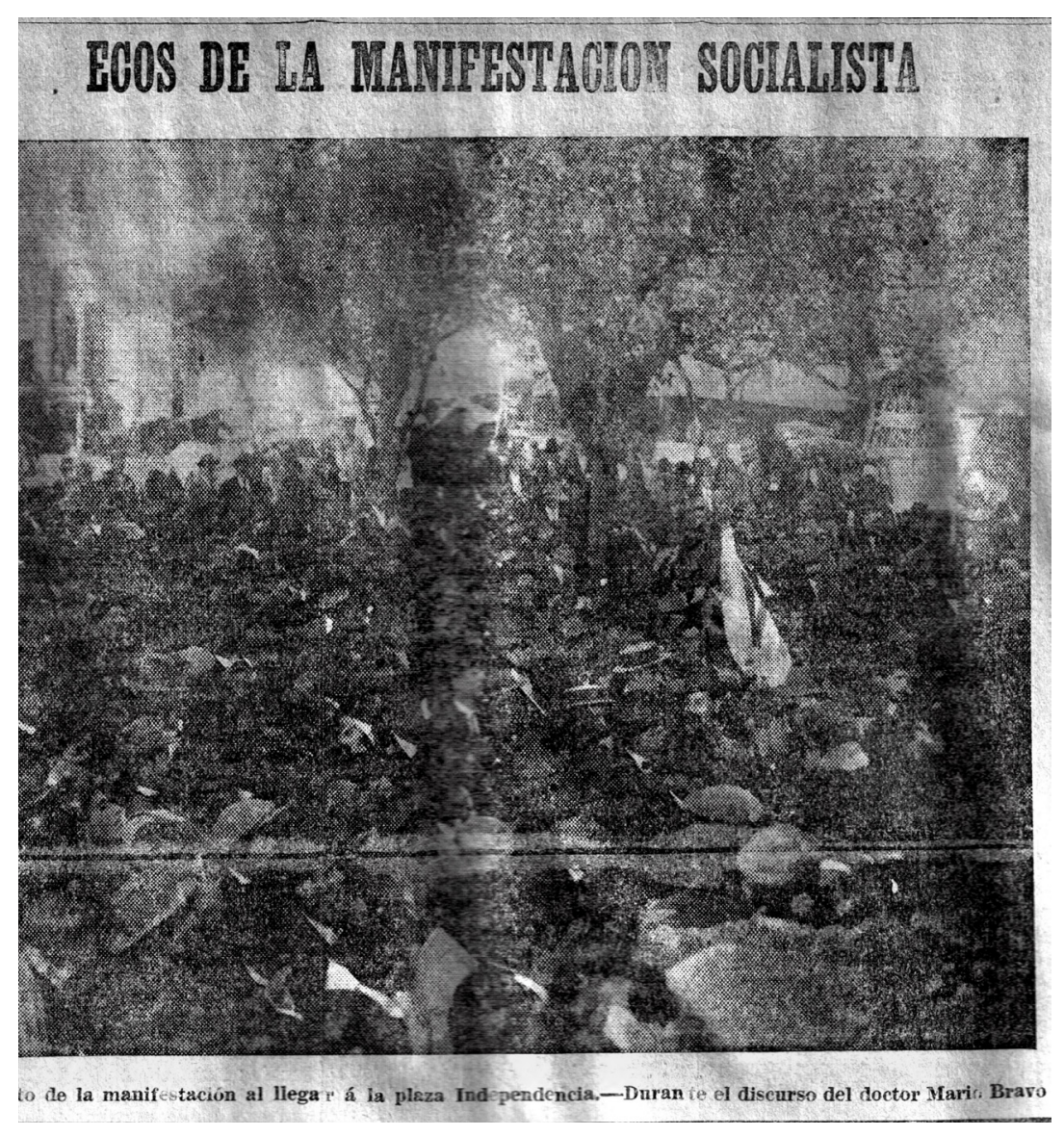

El Orden, 2/5/1914

La inclusión de esta imagen en las páginas del principal diario local de la época, El Orden, probablemente da cuenta del interés de la sociedad por la celebración de esta efeméride. Además, arroja datos sobre el afán por demostrar la fuerza de los trabajadores que en gran número acudían a la manifestación ocupando espacios públicos claves como la plaza Independencia. De esta forma, la fotografía podía convertirse en un testimonio del poderío del movimiento obrero que llegaba al centro de la ciudad para exhibir sus demandas y celebrar su principal conmemoración obrera. ${ }^{26}$ Para ello, resultaba fundamental demostrar a través de la imagen la significativa cantidad de asistentes al acto. Con lo cual, la fotografía se convertía en una herramienta idónea y posiblemente más eficaz que las palabras para transmitir la realidad. ${ }^{27}$ Asimismo, interesa mencionar que el título que encabezaba la foto "Ecos de la manifestación socialista" revelaba la asociación entre la evocación del $1^{\circ}$ de mayo y el socialismo, movimiento político que impulsaba esta conmemoración. 
Por su parte, la Federación Obrera local, de impronta anarquista, organizó otro mitin; sus militantes se reunieron inicialmente en la plaza Alberdi, en donde oyeron las palabras de varios oradores y luego la columna recorrió las calles Corrientes hasta 25 de Mayo para pasar por la calle 24 de Septiembre y de esta última por Congreso hasta la plaza Humberto I en donde se disolvió. Además, los trabajadores se detuvieron en la plaza Independencia para oír la palabra de otros oradores La fiesta del trabajo". ${ }^{28}$

El 1915 la conmemoración del $1^{\circ}$ de Mayo adquirió especial relieve, al contar con la presencia del Dr. Joaquín Apolinario, delegado del partido Socialista enviado por el Comité Nacional de dicha fuerza política a pedido de los militantes tucumanos. Sin embargo, los actos contaron con dificultades iniciales para su realización, tales como la negativa de las autoridades para autorizar el recorrido previsto por los trabajadores, rechazando su solicitud para llegar a la plaza Independencia, ante la sorpresa de la prensa que entendía como injustificada esta actitud de las autoridades, "ya que se trata de un mitin tradicional para el partido y al que en otras partes se facilita su realización, siempre que ofrezcan garantías de orden". ${ }^{29}$

Finalmente, se resolvió realizar el mitin en la plaza San Martín y desde allí partir a la plaza Alberdi, lugar designado para la disolución de la manifestación. Tal como estaba previsto, en ambas plazas los oradores pronunciarían discursos. Un testimonio visual de esta reunión fue la fotografía que mostraba al delegado socialista, el Dr. Apolinario, hablando a los manifestantes en la plaza Alberdi. Aunque poco clara, la imagen permite ver a los asistentes a la reunión pública rodeando el monumento a Alberdi y vestidos con trajes, corbatas o pañuelos, algunos con sombreros. Es decir, la fotografía servía como demostración de la fuerza del movimiento obrero al mismo tiempo que funcionaba como una prueba incuestionable de la capacidad de los trabajadores para vestirse elegantemente y participar de forma ordenada y pacífica en los espacios públicos. Asimismo, es factible pensar que esta fotografía que mostraba el correcto comportamiento de los manifestantes podía servir, a su vez, como un testimonio fundamental del capricho de las autoridades, quienes en un primer momento se habían negado a autorizar el acto. Con lo cual, El Orden se manifestaba como un actor primordial de la vida política. Mediante la difusión de fotografías de los participantes al acto del Primero de Mayo se posicionaba activamente en la escena pública asumiendo una postura concreta y respaldando por esa vía a los trabajadores afines al socialismo que protagonizaron el mitin (Figura 2). 
Figura 2

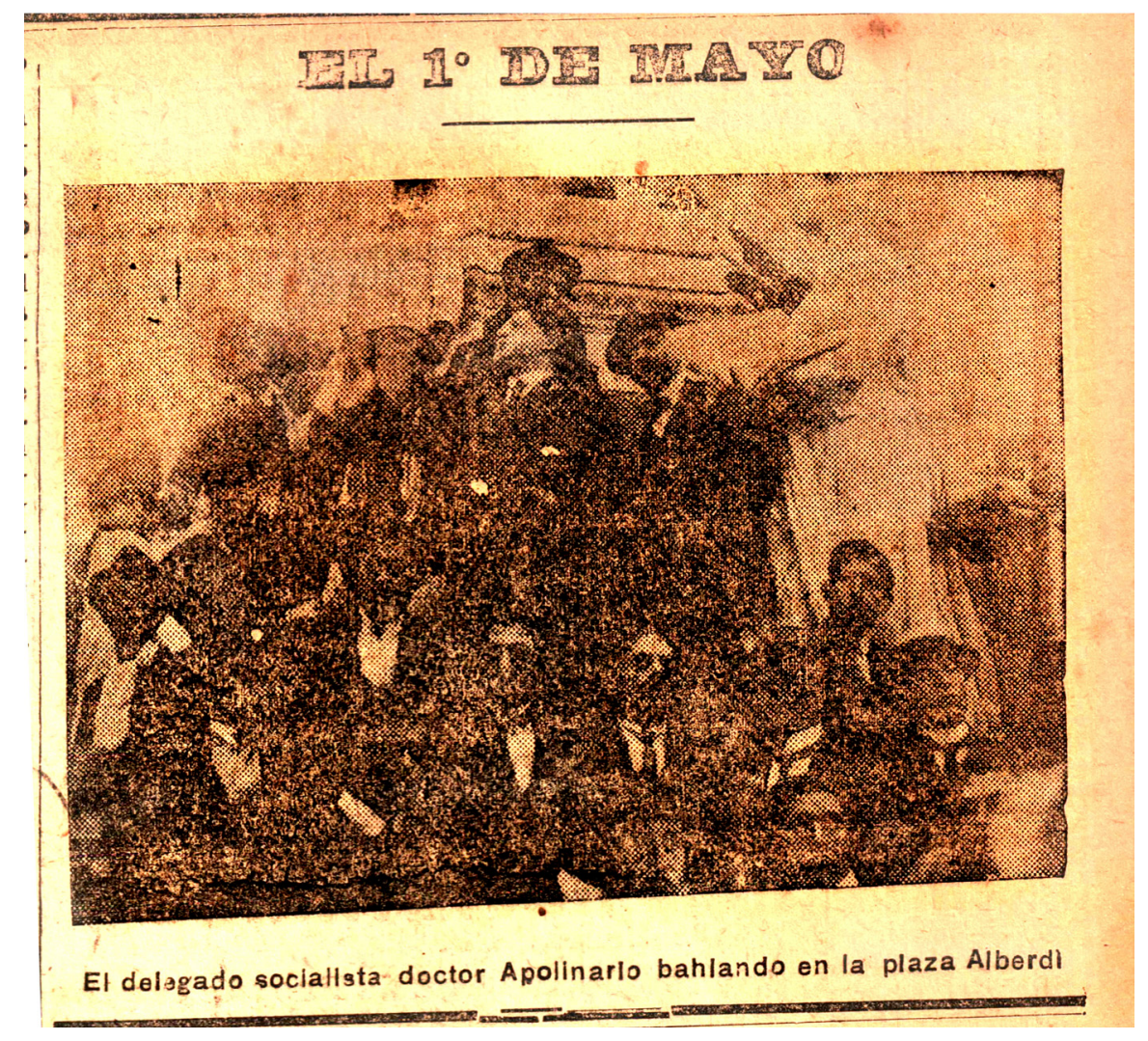

El Orden, 3/5/1915.

Además, el Centro Socialista, sección Tucumán, y el subcomité Juan Bautista Alberdi preparaban una velada en el teatro Odeón en homenaje a la fiesta del trabajo. El programa del evento incluía la ejecución de varios himnos revolucionarios, como La Marsellesa, Hijos del Pueblo y el Himno de los Trabajadores y la conferencia del delegado del comité ejecutivo del partido, el Dr. Joaquín Apolinario. ${ }^{30}$

Finalmente, otros actos para recordar el $1^{\circ}$ de mayo de ese año fueron convocados por asociaciones de trabajadores, como la Federación Obrera Ferrocarrilera que tenía previsto celebrar un mitin en la ciudad de Tafí Viejo y las agrupaciones anarquistas de la ciudad de San Miguel de Tucumán que proyectaban su propia manifestación. ${ }^{31}$

A las tradicionales manifestaciones de los trabajadores durante las conmemoraciones del $1^{\circ}$ de Mayo se les sumaron en 1916 algunas prácticas novedosas. Tal fue el caso del envío de delegados a la Casa de Gobierno con el fin de solicitar al gobernador una medida puntual: en este caso, el indulto al maquinista Reyes Romero, quien se encontraba preso en la cárcel 
penitenciaria desde hacía varios años por un homicidio. ${ }^{32}$ Con la mención a esta acción, en rigor, lo que me interesa destacar es cómo se inauguraba una instancia que luego caracterizaría a las manifestaciones de los trabajadores y en general del conjunto de reclamos de la población a lo largo de los años: acudir a la Casa de Gobierno, percibido como el lugar por excelencia del poder político provincial, ya que allí se encontraban las principales autoridades de gobierno: el primer mandatario y su gabinete.

Además, y como era costumbre, las movilizaciones organizadas por los socialistas para conmemorar el $1^{\circ}$ de Mayo complementaban la manifestación en calles o plazas con una velada que podía celebrarse en el local del centro obrero o en un espacio más amplio, como el Teatro Belgrano que ese año sirvió para la reunión en donde uno de los referentes del socialismo local, el Dr. Manuel Alurralde, disertó sobre las organizaciones obreras, la guerra europea y otros temas de actualidad. Por su parte, los anarquistas organizaron su propia conmemoración y dictaron varias conferencias en la plaza Humberto I, en donde hicieron uso de la palabra militantes como Menes, Delgado, Juncal, Viardot y Derisso. ${ }^{33}$ La mención de los nombres de los oradores que realizó la prensa permite conocer algo más sobre las expresiones del anarquismo en la provincia, tema tan poco trabajado y del cual disponemos, lamentablemente, muy escasas referencias. Con los datos disponibles, podemos proponer que uno de estos militantes libertarios era Tomás Delgado, muy activo en las prácticas del anarquismo local entre 1907 y 1908 y sobre el cual ya hicimos referencias antes en este trabajo. Otro activista sobre el cual contamos con información es Ángel Derisso, reputado como el principal responsable de una significativa protesta realizada por dependientes de comercio en el año 1912, conflicto que trajo aparejado la detención de varios trabajadores y la posterior elaboración de un proceso judicial. El litigo había concluido con la decisión de que uno de los presos "mayormente comprometido" sea "expulsado de la provincia por sus ideas avanzadas". ${ }^{34}$ Se trataba precisamente de Ángel Derisso, sobre el cual recayó la Ley de Residencia, aunque es factible suponer que esta medida finalmente no se aplicó, ya que Derisso participó de la manifestación del $1^{\circ}$ de Mayo de 1916, tal como acabamos de señalar.

Ya para terminar, me gustaría sugerir la construcción de recorridos y la delimitación de espacios de la protesta por parte de las distintas fuerzas que integraban el movimiento obrero. ${ }^{35}$ Así, por ejemplo, mientras los socialistas solían elegir para sus actos la plaza San Martín y la plaza Alberdi, los anarquistas empleaban la plaza Humberto I. Por otro lado, quisiera proponer la conformación de tradiciones de movilización, algunas de las cuales perduran hasta el día de hoy, como el reclamo frente a la Casa de Gobierno, epicentro del poder en la provincia y lugar en el cual confluyen invariablemente todas las manifestaciones de la población en la actualidad. Finalmente, y retomando el tema de las manifestaciones del $1^{\circ}$ de Mayo 
separadas que efectuaban anarquistas y socialistas, interesa anotar su relación con los distintos significados adjudicados a esta fecha por parte de ambos movimientos. Al respecto, podemos mencionar el manifiesto que distribuyó en 1916 el partido Socialista en Tucumán con el propósito de explicar la conmemoración del $1^{\circ}$ de Mayo. Allí, se afirmaba que

En Tucumán, como en toda la república, el partido Socialista realiza comicios públicos el $1^{\circ}$ de mayo, para reafirmar sus principios doctrinarios; para explicar a las nuevas generaciones el significado histórico de la gran fecha del porvenir, en su triple significado: de fiesta del trabajo, en su acepción prístina; de protesta, como exteriorización sumaria de los atentados diarios de que es víctima expiatoria la clase trabajadora, y de afirmación, en su convencimiento profundo de que con sus métodos de acción para la conquista de reformas que urge implantarlas. ${ }^{36}$

Si para el socialismo el $1^{\circ}$ de Mayo podía significar tanto un momento de afirmación de los trabajadores, una instancia de protesta y un episodio festivo, para el anarquismo, en cambio, se trataba únicamente de una efeméride de protesta que recordaba a las víctimas de la opresión y la explotación capitalista. ${ }^{37}$ En esa dirección, se trataban de usos irreconciliables que acompañaban a su vez miradas y proyectos distintos sobre los trabajadores $\mathrm{y}$, en líneas más generales, en torno a la sociedad y la vida pública. Por un lado, las banderas socialistas de lucha política y gremial y, por el otro, la consigna anarquista de la vía revolucionaria entendida como la única posibilidad para transformar la realidad. Gradualmente, y como sugiere Mirta Lobato, el sentido que se impuso fue el de los socialistas que consideraron esta fecha "como un día de fiesta, como un momento en el que el conjunto de los trabajadores se convertía en una sola voz y demostraba el grado de unidad y poder alcanzado en todas partes del mundo, aunque era también un día de recordación de los que habían caído bajo las garras del capitalismo. Para el anarquismo, en cambio, era un día de lucha y luto por los mártires de la insensibilidad burguesa". ${ }^{38}$

Hacia 1917 las movilizaciones del $1^{\circ}$ de Mayo alcanzaron mayores proporciones al involucrar la participación de un contingente numeroso de asistentes. "Ya no son más los grupitos de cincuenta o cien almas que se lanzan a la calle entonando sus himnos obreros; ayer se ha visto una columna de más de 1000 personas, desfilando por los distintos puntos de su recorrido", afirmaba la prensa local. Por su parte, los anarquistas también realizaron su conmemoración ese año y para ello se reunieron en la plaza Alberdi, en donde habló uno de sus militantes. Posteriormente, marcharon hacia la plaza 
Independencia, en donde el militante libertario Ángel Derisso, pronunció "un discurso lleno de bríos" y señaló "la diferencia que, para ellos, existía entre el $1^{\circ}$ de Mayo que preconizaba la Internacional Obrera y el verdadero significado de la fecha. Siguió luego la columna por calle Congreso, hasta la plaza Humberto I, donde volvió a hablar el señor Derisso, retirándose luego los manifestantes". ${ }^{39}$

La lluvia no consiguió opacar la conmemoración de 1918, ya que si bien ésta no tuvo el tradicional mitin en los espacios públicos, si pudo celebrarse a través de una asamblea en la plaza Independencia y una gran velada en el teatro Belgrano, reunión que además de una numerosa concurrencia contó con varios números de interés, como una conferencia, el estreno de una comedia denominada "Ángela" y la representación de un aplaudido sainete titulado "A primera sangre". ${ }^{40}$

En 1919, en un contexto tensado por el incremento de la conflictividad obrera y la represión del Estado y de los patrones hacia los trabajadores, numerosos gremios de la provincia resolvieron declarar el paro general de actividades durante el primero de mayo, mientras los servicios considerados indispensables como los ferrocarriles llevarían adelante un paro parcial, es decir de medio día. De acuerdo con esta medida, numerosos establecimientos industriales y casas de comercio cerraron sus puertas y clausuraron sus labores ordinarias, otorgando descanso por 24 horas a sus obreros y empleados. ${ }^{41}$

Se anunciaba así la tradición del Primero de Mayo como un día no laborable. La paralización de actividades durante ese día contribuyó seguramente al éxito del mitin socialista convocado para esa fecha y en el cual participaron 1.600 personas, según cifras proporcionadas por la prensa. Pero el significado de no trabajar ese día era mayor. Traspasaba su papel en la eficacia y la amplitud de la concentración obrera e implicaba una verdadera demostración del poder de los trabajadores. Como sugiere Eric Hobsbawm, “abstenerse de trabajar en un día laborable era a la vez una afirmación del poder obrero - de hecho, la afirmación por excelencia de dicho poder-- y la esencia de la libertad, a saber: no verse obligado a trabajar con el sudor de la frente, sino hacer lo que quisieras en compañía de la familia y los amigos". ${ }^{42}$

En un clima de radicalización de los conflictos sociales y obreros y sobre todo en el marco del recrudecimiento del accionar represivo del Estado, los patrones y los segmentos más conservadores, ${ }^{43}$ podemos situar la intervención del gobierno nacional para reforzar las medidas de seguridad ese mayo de 1919. Esta política se reflejó en el envío desde la vecina provincia de Salta de un escuadrón de la 13 caballería que acampó en las afueras del municipio de San Miguel de Tucumán y en las estaciones ferroviarias con el objetivo de la normalización de los servicios. Además, se resolvió que una sección de soldados se ubicara en la localidad de Tafí Viejo para custodiar los talleres del Estado - cabe señalar que allí se encontraban los talleres 
ferroviarios. ${ }^{44}$

El número de participantes en las manifestaciones del $1^{\circ}$ de Mayo continuó en aumento y en 1920, una cifra estimada de 1500 ciudadanos se reunió en el cruce de las calles Alberdi y Crisóstomo Álvarez para llegar después hasta la plaza Lamadrid, en donde hablaron dirigentes del socialismo local y nacional, como el Dr. Federico Pinedo, enviado por el partido Socialista. A diferencia de otros años, en los cuales la postura de la prensa se había mostrado más cautelosa, esta vez se difundió un artículo firmado por su autor, Ricardo Huiracocha, quien no escatimó críticas en torno a las prácticas de organización de los socialistas tucumanos. Según esta nota, ya que los compañeros de Tucumán habían logrado realizar manifestaciones de 1500 personas, "podían comprender la utilidad de nombrar dos o tres comisarios de columna. Estos comisarios podrían darle la organización de que careció la manifestación del $1^{\circ}$, pues sus indicaciones, hechas con amabilidad y corrección, no son desatendidas por los manifestantes!” En contraste, la intervención de Federico Pinedo mereció los entusiastas elogios de Huiracocha, expresados en su valoración como un excelente orador, de la talla de Justo, caracterizado por una "sencillez y claridad, que solo es accesible a los que piensan sencilla y claramente, sin complicar las cuestiones que tratan". ${ }^{45}$

\section{LOS AÑOS 1920 Y LA MOVILIZACIÓN DE LOS TRABAJADORES}

Mayo de 1921 fue testigo de la presencia en Tucumán de una nueva fuerza política, como el comunismo, movimiento que encabezó una manifestación para el $1^{\circ}$ de Mayo en las plazas Humberto I y la plaza Lamadrid, donde varios oradores pronunciaron discursos que, en líneas generales, contrastaban con las premisas reformistas del socialismo y marcaban una instancia diferente en la lucha de los trabajadores en la provincia. ${ }^{46} \mathrm{~A}$ su vez la conmemoración del $1^{\circ}$ de Mayo de ese año fue objeto de otras movilizaciones, como la convocada por la FORA que llevó adelante un gran mitin a las 10 de la mañana de ese día y en el cual participaron los gremios adheridos a dicha federación que después de recorrer varias calles se detuvieron en la plaza Independencia al frente de las escalinatas de la Casa de Gobierno, donde hicieron uso de la palabra algunos dirigentes y militantes. Por su parte, los socialistas motorizaron una amplia manifestación que reunió a más de 2000 asistentes y contó con los discursos de la dirigencia local aunque no con la anunciada visita de una de las máximas figuras del socialismo argentino, como el Dr. Enrique del Valle Iberlucea, quien en otras oportunidades había participado de actos de propaganda obrera efectuados en Tucumán. Por la noche, además, el socialismo efectuó una velada literario- 
musical que tuvo lugar en uno de los principales espacios culturales de la provincia, el teatro Odeón, y contempló un programa que incluyó himnos y cantos revolucionarios como La Internacional, Hijos del Pueblo y el Himno de los Trabajadores, así como conferencias, disertaciones poéticas y comedias, como la representación de "El Ordenanza" ${ }^{47}$

Paralelamente, aumentaba la difusión del socialismo en Tucumán, tal como se evidenció en 1922 cuando los socialistas lograron penetrar con más fuerza en el interior de la provincia, al celebrar allí varios actos de propaganda partidista y atraer a los mismos a una amplia concurrencia. Si nos guiamos por los datos recogidos en la prensa podemos afirmar que un numeroso público se reunió en las villas de Monteros, Aguilares, Río Colorado, Bella Vista, Villa Luján y en el ingenio Lastenia, espacios a los cuales asistieron todos los oradores designados por el partido. ${ }^{48}$ Para conmemorar el $1^{\circ}$ de Mayo de ese año los socialistas organizaron en la ciudad de San Miguel de Tucumán una amplia manifestación que contó con una asistencia aproximada de 4000 personas. Probablemente la presencia del diputado nacional De Andreis que vino a Tucumán para participar del evento contribuyó a otorgar mayor importancia al mitin, objeto de una fotografía difundida en las páginas de $\mathrm{El}$ Orden. Dicha imagen mostraba a un grupo de manifestantes elegantemente vestidos con trajes para la ocasión y publicitando las demandas del Primero de Mayo a través de carteles que colgaban en la parte frontal de su cuerpo; además puede observarse a algunos niños acompañando la manifestación (Figura 3).

Figura 3

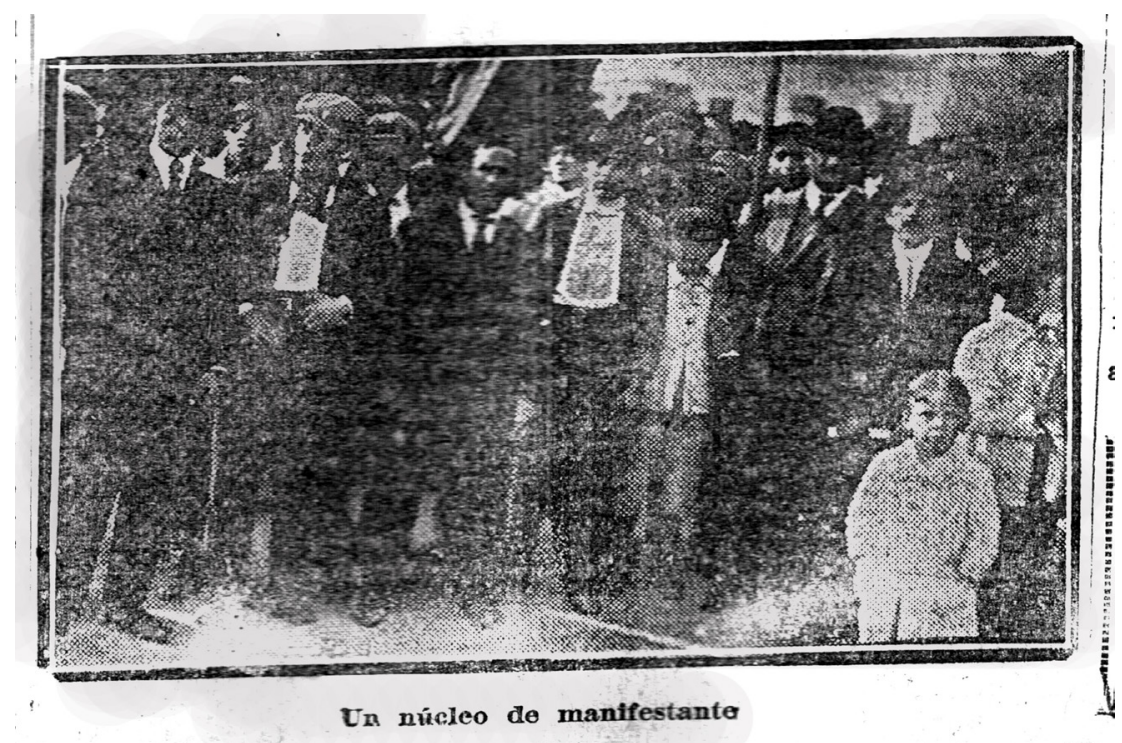

El Orden, 2/5/1922. 
Las imágenes publicadas en la prensa tucumana para retratar el $1^{\circ}$ de mayo revelaban la importancia de la movilización de los trabajadores durante esa efeméride central del calendario obrero mediante el empleo de la foto como evidencia de la realidad. En el caso concreto de la fotografía recientemente mencionada, El Orden recortaba un grupo de manifestantes y mediante un acercamiento de la cámara permitía detectar gestualidades, pancartas e incluso la presencia de menores en el evento, lo cual contribuía a otorgar un carácter más familiar y próximo a la manifestación de los trabajadores.

Al despuntar el año 1923, concretamente en enero, se dictó una ley clave para los trabajadores, como la ley que establecía el salario mínimo y dos meses después, en marzo de ese mismo año, se emitió la ley que fijaba la jornada de 8 horas. ${ }^{49}$ En ese contexto, tuvieron lugar las celebraciones del el $1^{\circ}$ de Mayo, recordado ese año mediante una velada realizada en el teatro Politeama Argentino que atrajo una "extraordinaria cantidad de público" y concluyó con la conferencia del Dr. Federico Pinedo, en su carácter de delegado del Comité Ejecutivo del partido Socialista. Además, se desarrolló el tradicional mitin organizado por el socialismo que se plasmó en una multitudinaria manifestación retratada en dos fotografías publicadas por la prensa. En una de esas fotos puede verse al dirigente Federico Pinedo llevado en andas por la multitud (Figura 4), mientras en la otra imagen sobresale la presencia de algunas mujeres entre los numerosos integrantes de la manifestación que ocupaba las escalinatas de la Casa de Gobierno (Figura 5).

Figura 4

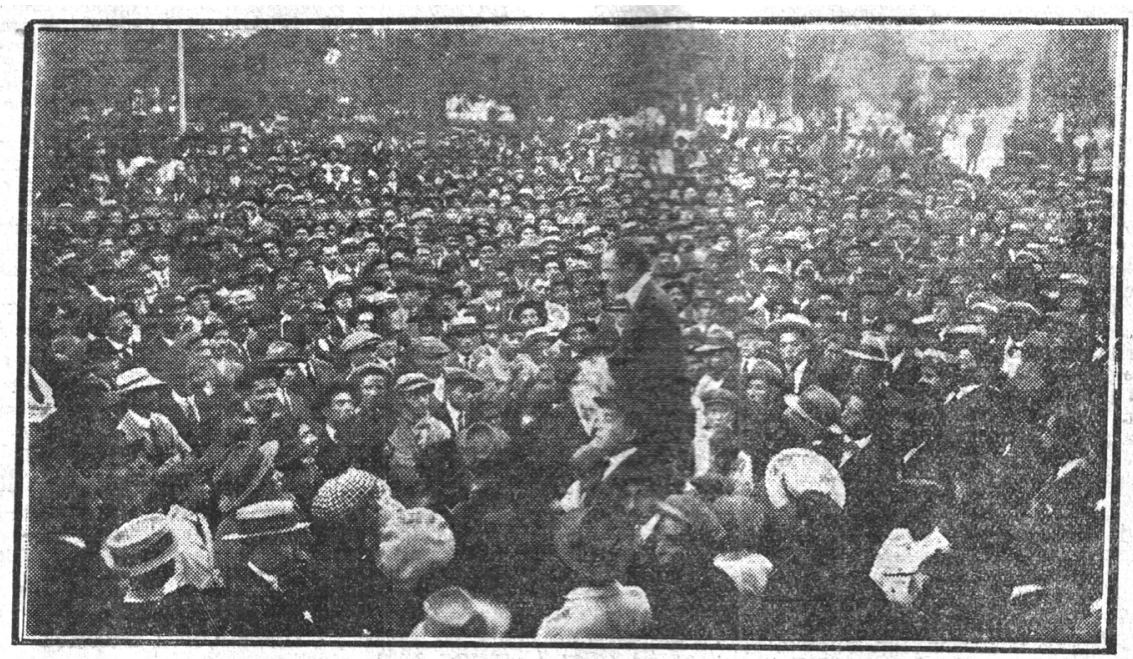

EA Dr. Federico Pinedo, delegado de 1 C. E. del Partido Socialista, diri giendo la palabra a los manirestantes

El Orden, 27/5/1923 
Figura 5

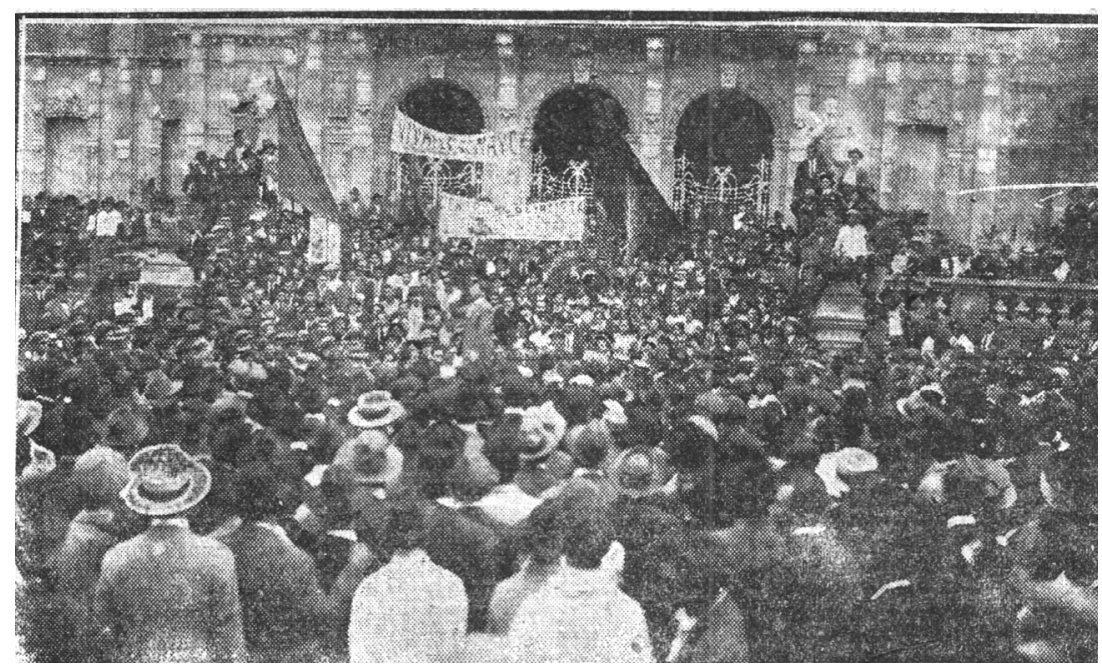

El Orden, 27/5/1923

Sin ánimo de agotar el tema con estas páginas, me gustaría subrayar algunas cuestiones. En numerosos diarios y semanarios obreros de Argentina y del extranjero el Primero de Mayo era representado mediante ilustraciones, generalmente grabados y dibujos que mostraban al pueblo "rompiendo las cadenas de la explotación, el amanecer de un nuevo mundo, a los trabajadores marchando con sus banderas de libertad y justicia o expulsando de la tierra a patrones, militares y sacerdotes". ${ }^{50}$ Sin embargo, lo que observamos en las imágenes publicadas en la prensa tucumana eran fotografías que revelaban la importancia de la movilización de los trabajadores para recordar el $1^{\circ}$ de mayo, mediante el empleo --ya señalado-- de la foto como evidencia de la realidad. La cantidad de manifestantes que rodeaban la figura del renombrado líder socialista Federico Pinedo, la atención y el compromiso con el evento que revelaban los rostros de los trabajadores al oír sus palabras --tal como puede observarse en la fotografía 4-- se completaba con la atenta escucha de los manifestantes, hombres y mujeres, en la conferencia del dirigente del socialismo Emilio López, que se desprende de la fotografía 5. Si nos guiamos por estos registros gráficos tiene sentido pensar que las manifestaciones del Primero de Mayo iban incrementando su importancia, creciendo en número, atrayendo al público femenino y captando en definitiva la atención de la prensa que lejos de mostrarse como un actor pasivo intervenía activamente en la arena pública. Podemos sugerir que las fotografías no se tomaban al azar. Por el contrario, resulta factible suponer que el fotógrafo de $\mathrm{El}$ Orden seleccionaba muy bien la escena a retratar, reflexionaba en torno al mensaje 
que buscaba trasmitir mediante las imágenes y, en esa dirección, el resultado era el buscado. Por ejemplo, un cuadro imponente era la fotografía 5 que mostraba a los trabajadores (hombres y mujeres) participando con corrección, interés y compromiso de las actividades organizadas para evocar el $1^{\circ}$ de mayo. En dicha foto, el centro de la ciudad, representado por la Casa de Gobierno, colmado por los trabajadores que llegaban allí con sus banderas y prestaban atención a las palabras que les dirigían los líderes socialistas desde las escaleras de la sede del poder contribuía sin duda a otorgar mayor fuerza a la imagen.

Mirta Lobato señalaba en su análisis sobre el tema para el Río de la Plata que "la presencia de las masas trabajadoras movilizadas en las calles generaba inquietud en las autoridades, no solo en Buenos Aires y en Montevideo sino también en las ciudades europeas como París, Berlín, Munich". ${ }^{51}$ ¿Qué actitud asumió el gobierno de Tucumán ante esta influencia obrera expresada durante los $1^{\circ}$ de mayo? es uno de los interrogantes que se desprende del análisis que efectuamos sobre el tema. Al respecto, me gustaría sugerir que hacia mediados de los años 1920, la costumbre de no trabajar los primeros de mayos se reveló con mayor claridad y, con el tiempo, esta práctica se fijaría en el repertorio de expresiones obreras con una fuerza inusitada. Para entones, también, es factible detectar transformaciones en las movilizaciones del Primero de Mayo, en especial a partir de la decisión del Estado de declarar feriado a esta efeméride en un intento de apropiación del ritual obrero.

En efecto, la jornada de mayo de 1924 fue testigo de una ciudad casi paralizada. Con prácticamente la totalidad de sus actividades suspendidas durante las conmemoraciones del Primero de Mayo, San Miguel de Tucumán ofreció el espectáculo de una ciudad muerta. Todos los gremios de trabajadores urbanos, con excepción de los tranviarios, se habían plegado a la fiesta del $1^{\circ}$ de Mayo, declarando el paro por 24 horas..$^{52}$ Según relatos de la prensa, el silencio de la urbe solo había sido interrumpido por la manifestación organizada por el partido Socialista que después de recorrer varias calles de la ciudad entre vivas al $1^{\circ}$ de Mayo y cantos alusivos confluyó en la plaza Independencia, en donde algunos oradores dirigieron la palabra a un auditorio estimado en aproximadamente 1500-1600 personas. En especial, sobresalió el discurso del delegado del partido Socialista metropolitano, el dirigente Muzzio, quien se refirió a la fecha consagrada al trabajo y la relacionó con la ley de jubilaciones gremiales, señalando también las importantes lagunas que en su opinión presentaba su reglamentación y obstaculizaban su aplicación inmediata. $^{53}$

En 1925, el Poder Ejecutivo de la Nación tomó una decisión que gradualmente modificaría radicalmente el significado del Primero de Mayo dentro de la tradición obrera, al declarar feriado a esa fecha "en homenaje al luctuoso aniversario que representa ese día para la clase trabajadora del 
mundo". Por su parte, el Poder Ejecutivo de la provincia logró obtener rápidamente de legislatura la sanción de una ley análoga. Por esta vía, el gobierno se apropiaba de una conmemoración propia del universo de los trabajadores y trastocaba el sentido otorgado a la decisión de las asociaciones obreras de no trabajar los primeros de mayo. Al establecer que ese día sería feriado, el Estado podía cambiar las nociones vinculadas con la jornada obrera, quitándole su cariz revolucionario y de protesta para incorporarlo en el calendario cívico nacional.

\section{ALGUNAS CONSIDERACIONES FINALES}

En este trabajo nos propusimos examinar la construcción del ritual del Primero de Mayo en Tucumán. Para ello, tratamos de avanzar en los orígenes de esta conmemoración en la provincia, cuando hacia finales de la década de 1890 los militantes del Centro Cosmopolita de Trabajadores pusieron en marcha veladas literario-musicales, desarrolladas en la sede asociativa $\mathrm{y}$ en las cuales un momento fundamental eran los discursos y conferencias impartidos por los militantes y líderes obreros afines a distintas corrientes de izquierda en el mundo del trabajo como el anarquismo y, en especial, el socialismo, movimiento que gradualmente alcanzó mayor influencia en las prácticas asociativas de este espacio obrero. Otra instancia fundamental de las conmemoraciones eran las manifestaciones en calles y plazas de la ciudad, en donde los dirigentes, al igual que en las reuniones celebradas en locales de los centros obreros como el Centro Cosmopolita, explicaban la historia y definían los significados en torno a esta efeméride, al tiempo que destacaban los avances del movimiento obrero, mencionando sus conquistas y subrayando, además, el camino que faltaba recorrer para alcanzar mejores condiciones de vida y de trabajo. En esa dirección, aprovechaban la ocasión del Primero de Mayo para difundir la propaganda socialista y exhortar a los trabajadores a robustecer sus esfuerzos para trabajar a favor de dicha fuerza política presentada como la única capaz de defender y luchar por los derechos de los trabajadores.

Al promediar la década de 1910, las manifestaciones públicas del $1^{\circ}$ de Mayo se volvieron cada vez más numerosas, en consonancia con el avance del socialismo que potenciado por el triunfo electoral obtenido en la Capital Federal robusteció sus trabajos de propaganda en Tucumán y difundió su programa incluso en las localidades del interior de la provincia. En especial fue la ciudad de San Miguel de Tucumán el escenario recorrido por trabajadores que visibilizaban sus demandas conformando itinerarios de ocupación de los espacios públicos que en algunos casos se mantienen hasta la fecha. Al respecto, podemos mencionar la costumbre de la población, configurada durante el periodo estudiado, de movilizarse hasta la plaza Independencia, principal paseo público de la ciudad y, más especialmente, 
frente a la Casa de Gobierno, sede del gobierno provincial, para hacer oír sus reclamos. Además, y como era usual en los mítines del $1^{\circ}$ de Mayo liderados por el socialismo, en las reuniones estaban presentes un conjunto de atributos comunes, como la organización de los trabajadores en secciones, el uso de estandartes y símbolos, como la bandera roja, la entonación de himnos revolucionarios, el recorrido pacífico por las principales calles y plazas de la ciudad y la exhibición de consignas alusivas a la fecha. Ahora bien, tiene sentido proponer que tales características no eran privativas de Tucumán y ni siquiera de otras provincias argentinas sino que estaban presentes en las manifestaciones públicas de los trabajadores en diversas latitudes de América Latina, en donde las jornadas del Primero de Mayo servían para exhibir y reforzar el poder del movimiento obrero, al tiempo que reflejaban la disputa de las distintas fuerzas obreras y políticas por imponer los sentidos y liderar la principal conmemoración de los trabajadores. A su vez, las celebraciones del $1^{\circ}$ de Mayo podían revelar la influencia de procesos revolucionarios europeos, especialmente de los sucesos que ocurrían en Rusia con el triunfo del gobierno obrero. ${ }^{54}$

Asimismo, en una tónica semejante a lo que sucedía en otras provincias argentinas y, en general, en varios países de América Latina, las movilizaciones del $1^{\circ}$ de Mayo conformaron espacios de disputa entre las distintas fuerzas que competían por el liderazgo en el mundo del trabajo. A grandes rasgos, podemos sugerir que para los socialistas, el Primero de Mayo conformaba un momento de protesta y de lucha obrera, pero también --como sugiere Mirta Lobato-- de manifestación pacífica de los trabajadores que se pronunciaban por sus derechos, demostrando su unidad y exhibiendo su fuerza. Con lo cual, la conmemoración del $1^{\circ}$ de Mayo podía articular la noción de protesta y lucha obrera con el significado festivo y de afirmación de la clase trabajadora. En contraste, los anarquistas rescataban únicamente el carácter de protesta de esta efeméride que se entendía como una jornada luctuosa, de rebelión y homenaje a las víctimas de la opresión y la explotación capitalista. Gradualmente, la distancia entre el socialismo y el anarquismo se expresó en Tucumán a través de la realización de actos diferenciados para evocar el Primero de Mayo. De esta forma si, por ejemplo, el socialismo convocaba a sus militantes a concentrarse en una zona determinada de la ciudad y desde allí seguir un recorrido que atravesaba distintos puntos céntricos para arribar finalmente a alguna de las principales plazas, los anarquistas preparaban otro trayecto para la conmemoración. Y aunque a veces podían coincidir, por lo general, cada grupo tenía sus espacios característicos que paulatinamente fueron identificando sus manifestaciones.

Más adelante, con la radicalización de los conflictos obreros y el recrudecimiento del accionar represivo de los patrones y del Estado hacia los trabajadores que caracterizó el periodo comprendido, aproximadamente, entre 1917 y 1919, las movilizaciones del $1^{\circ}$ de Mayo cobraron mayor vigor, 
reflejando al mismo tiempo las tensiones y las divisiones al interior del movimiento obrero. En este trayecto, el año 1919 fue especialmente virulento. En un contexto tensado por la radicalización de la protesta y la violencia del gobierno y de los sectores patronales a los obreros, acompañado por el clima de ideas conservadoras y xenófobas difundidas entonces, los gremios y las centrales obreras resolvieron decretar el paro general de actividades durante el $1^{\circ}$ de Mayo. Es probable que la decisión de los dirigentes y militantes obreros de no laborar durante dicha jornada contribuyera a incrementar la participación de los trabajadores en las manifestaciones, al tiempo que revelaba la fuerza que había adquirido la organización del movimiento obrero en la provincia.

Una nueva etapa comenzó a gestarse al promediar la década de 1920, cuando el gobierno definió al $1^{\circ}$ de Mayo como día feriado, sugiriendo el tránsito del Primero de Mayo como una celebración característica de los trabajadores a la re-significación y apropiación de esta efeméride por parte del Estado. En esa dirección, poco faltaría para que se abrieran paso las consideraciones del $1^{\circ}$ de Mayo como un día patriótico-festivo y el gobierno tuviera cada vez más peso en su celebración, pero esto ya forma parte de otra historia.

\section{NOTAS}

1 Sin ánimo de mencionar toda la bibliografía sobre el tema, resultaron sumamente valiosos y sugerentes los aportes de MELGAR BAO, Ricardo, El movimiento obrero latinoamericano. Historia de una clase Subalterna. Madrid: Alianza Editorial, 1988, VIGUERA, Aníbal, El primero de mayo en Buenos Aires, 1890-1950: evolución y usos de una tradición, Boletín del Instituto de Historia Argentina y Americana "Dr. E. Ravignani”, Tercera Serie, $\mathrm{N}^{\circ} 3$ (1991): 57-58; SURIANO, Juan, Cultura y política libertaria en Buenos Aires, 1890-1910. Buenos Aires: Ediciones Manantial, 2001; LOBATO, Mirta Zaida, La prensa obrera. Buenos Aires: Edhasa, 2009, LOBATO, Mirta Zaida y PALERMO, Silvana Alejandra, Del trabajo a las calles: dignidad, respeto y derechos para los y las trabajadoras. En LOBATO, Mirta Z., Buenos Aires. Manifestaciones, fiestas y rituales en el siglo XX. Buenos Aires: Biblos, 2011, pp. 45-74; POY, Lucas, "Socialismo y anarquismo en los orígenes del Primero de Mayo en Argentina (1890-1895), Trabajadores, Año 1, N 2, Segundo Semestre, 2011, pp. 27-57. HOBSBAWM, Eric, El nacimiento de una fiesta: El Primero de Mayo. En HOBSBAWM, Eric, Gente poco corriente. Resistencia, rebelión y jazz. Buenos Aires: Crítica, 2013, pp. 132-147 y BILHÃO, Isabel, Dia de festa, dia de luto ou feriado nacional? As diferentes concepções do Primero de Maio no Brasil ao longo dos anos 1929, Hib, Revista de Hitoria Iberoamericana, Vol. 6, $\mathrm{n}^{\circ}$ 1, 2013, pp. 29-52.

2 El Orden fue creado en 1883 por Ernesto Columbres y fue el diario de más larga vida en Tucumán; incluso para 1948 seguía existiendo, aunque ya muy disminuido. Al respecto, GARCÍA SORIANO, Manuel, El periodismo tucumano: 1817-1900. Ensayo de investigación sobre un aspecto de la cultura de Tucumán durante el siglo XIX, Cuadernos de Humanitas, 38, Tucumán, Universidad Nacional de Tucumán, Facultad de Filosofía y Letras, 1972, 3039. 
3 Hacia 1902-1903, la "Unión Provincial", fuerza política encabezada por Lucas Córdoba que hasta entonces había sido hegemónica se dividió y los escindidos del grupo constituyeron un nuevo partido: la "Unión Popular", compuesto por el grueso de los industriales azucareros que eran hostiles a Lucas Córdoba (BRAVO, María Celia, Liberales, socialistas e Iglesia frente a la situación de los trabajadores en Tucumán. En Suriano, J., La cuestión social en la Argentina, 1870-1943, Editorial La Colmena, Buenos Aires, 2000, pp. 31-61).

4 Denominación que hacía alusión directa a la figura del gobernador Lucas Córdoba (BRAVO, 2000, op. cit., pp. 31-61).

5 Agradezco a María Ullivarry la facilitación de la publicación anarquista Germinal.

6 REPETTO, Nicolás, Mi paso por la política. De Roca a Irigoyen. Buenos Aires: Santiago Rueda Editor, 1956 y LOTITO, Luis, El proletariado tucumano a comienzos de siglo. En DI TELLA, Torcuato (comp.), Sindicatos eran los de antes, Buenos Aires: Biblos/Fundación Simón Rodríguez, 1993.

7 En especial nos apoyamos en las sugerencias y los aportes provenientes de los trabajos de VIGUERA, op. cit. 1991, SURIANO, op. cit., 2001, LOBATO, op. cit., 2009, LOBATO y PALERMO, op. cit., 2011, pp. 45-74, POY, op. cit., 2011, para Argentina, y BILHÃO, op. cit., 2013, pp. 29-52, sobre Brasil.

8 En esa dirección y, como ya fue sugerido por la bibliografía sobre el tema, las versiones del pasado sirven a las luchas en el presente. Al respecto Alejandro Cattaruzza sugiere que "la utilización de representaciones del pasado exhibe características propias. La primera de ellas es que siempre se trata de una competencia y un debate entre varias lecturas de la historia. La segunda, que esos debates tienen un objeto declamado, y ciertamente auténtico, constituido por las imágenes del pasado, y otro implícito, tan auténtico como el anterior, que se define en el presente y está asociado a los conflictos político-sociales del momento". Al comparar las conmemoraciones del Centenario de la Revolución de Mayo en Argentina con las evocaciones del $1^{\circ}$ de Mayo, Cattaruzza sostiene que desde hacía casi veinte años los trabajadores evocaban estas fechas "en las que se apelaba al pasado y a los símbolos propios, aunque esta vez la identidad en cuestión fuera la de clase" (CATTARUZZA, Alejandro, Los usos del pasado. La historia y la política argentinas en discusión, 1910-1945. Buenos Aires: Sudamericana, 2007, pp. 19, 29.36).

9 De acuerdo con una lectura de las producciones existentes en el campo de la historia de los trabajadores, tanto para Argentina como para otros países de América Latina, se desprende la influencia que desde hace ya algunos años alcanzan ejes de análisis vinculados con las expresiones de asociación, protesta, sociabilidad y cultura de los trabajadores. Aunque los avances obtenidos desde estas perspectivas analíticas son notables, la mayoría de los estudios priorizan el análisis de las provincias y ciudades más dinámicas de las geografías nacionales. Para una revisión completa de las contribuciones actuales en este campo se pueden ver, IÑIGO CARRERA, Nicolás, La historia de los trabajadores. En GELMAN, Jorge (comp.), La historia económica en la encrucijada. Buenos Aires: Prometeo, 2006; SURIANO, Juan, Los dilemas actuales de la historia de los trabajadores. En GELMAN, op. cit., 2006 y ¿Cuál es hoy la historia de los trabajadores en Argentina?, Revista Mundos do Trabalho, Vol. 1, N ${ }^{\circ}$ 1, Janeiro-junho, 2009, pp. 27-50. Para otros contextos latinoamericanos, FRENCH, John D., El auge los estudios sobre el trabajo en Latinoamérica, Historia Social, No 39, 2001, pp. 129-150 y VAN DER LINDEN, Marcel, La globalización de la historia del trabajo y de la clase obrera y sus consecuencias. En SANZ ROSALÉN, Vicent y PIQUERAS, José Antonio, En el nombre del oficio. El trabajador especializado: corporativismo, adaptación y protesta. Madrid: Biblioteca Nueva, 2005. 
10 Un trabajo sumamente sugerente sobre el nacimiento del Primero de Mayo como una fiesta internacional del movimiento obrero, celebrada por primera vez en 1890, es el de HOBSBAWM, op. cit., 2013, pp. 132-147.

11 El Orden, 12/04/1901.

12 Definida como una fecha esencial del calendario obrero, el Primero de mayo era percibido como un ritual fundamental para el socialismo, que inauguró esta tradición, y una fecha central para el anarquismo, en tanto era "el único aniversario asociado exclusivamente con el proletariado", tal como lo señala SURIANO, op. cit., 2001, p. 318.

13 Acerca de este tema puede consultarse, por ejemplo, el artículo de VIGUERA, op. cit., 1991, pp. 57-58, en donde señala cómo bandas de música que ejecutaban el Himno a los Trabajadores, La Marsellesa y otras canciones obreras, y manifestantes portando banderas rojas formaban parte esencial de las marchas organizadas por los socialistas los $1^{\circ}$ de mayo.

14 Como señalaba un estudioso sobre el tema, Ricardo Falcón, en la época se entendía "la acción parlamentaria futura como instrumento fundamental para la conquista de reformas democráticas generales y económico-sociales de los trabajadores". De acuerdo con esa perspectiva, el partido Socialista insistía en la importancia de que los trabajadores extranjeros se naturalizaran con vistas al ejercicio de los derechos electorales (FALCÓN, Ricardo, Izquierdas, régimen político, cuestión étnica y cuestión social en Argentina (1890-1912), Estudios Sociales, revista universitaria semestral, año XXI, N ${ }^{\circ} 40$ 2011, p. 198).

15 La Vanguardia, 10/5/1902.

16 El Orden, 27/04/1901 y 2/05/1901.

17 La Estrella del Norte, 14/5/1905.

18 La Estrella del Norte, 14/5/1905.

19 BILBAO, Santiago, Anarquismo en el noroeste a principio del siglo XX: Germinal, publicación tucumana, en Estudios del Trabajo, N ${ }^{\circ} 28$, 2004, pp. 143-151. Además, Delgado participó encabezando la velada y la conferencia libertaria dedicada a las clases trabajadoras organizada por esta Federación Obrera Local en septiembre de 1907 en el Teatro Belgrano. Inaugurado con las palabras del líder de la Federación, Tomás Delgado, el acto incluyó también cantos revolucionarios, declamaciones poéticas y las palabras de dirigentes provinciales y delegados de la FORA (El Orden, 27/9/1907).

20 Germinal, 1908, 1/5/1908.

21 El Orden, 29/08/1901, 27/08/1904, 8/06/1905, 11/11/1905, 26/07/1906 у 1/03/1909.

22 Germinal, 1908, 1/5/1908.

23 Sobre este tema, no está demás mencionar los análisis recientes de SURIANO, Juan y ANAPIOS, Luciana, Anarquistas en las calles de Buenos Aires (1890-1930). En LOBATO, Mirta Z., Buenos Aires. Manifestaciones, fiestas y rituales en el siglo XX. Buenos Aires: Biblos, 2011, quienes sugieren como "la suma de retórica violenta y gestualidad agresiva alimentaba temores que se exacerbaban en momentos de mayor conflictividad, especialmente cuando el anarquismo logró cierto éxito entre los trabajadores entre 1901 y 1910 o en torno a la Semana Trágica de 1919". Y aunque era claro el nivel de violencia que podían alcanzar las prácticas anarquistas, esto no significaba que las mismas no se desarrollaran en un marco de orden, ya que como bien lo advierten los autores, orden y violencia no necesariamente se oponen entre sí.

24 El Orden, 1/05/1906 y 4/05/1909. 
25 El Orden, 27/4/1914 y 1/5/1914.

26 BILHÃO, op. cit., 2013, pp. 29-52.

27 En esa dirección, resulta pertinente recuperar las apreciaciones de Mirta Lobato, quien al estudiar la prensa obrera en el Río de la Plata señala como "el uso de la imagen fotográfica en la prensa gremial era acorde con el discurso del siglo XIX sobre fotografía, es decir, como representación de lo real [...] Probablemente también le atribuían a las fotos la capacidad para transmitir un mensaje que las palabras estaban imposibilitadas de comunicar" (LOBATO, op. cit., 2009, p. 90).

28 El Orden, 27/4/1914 y 1/5/1914.

29 El Orden, 28/4/1915.

30 El Orden, 3/5/1915.

31 El Orden, 30/4/1915.

32 El Orden, 3/5/1916.

33 El Orden, 3/5/1916.

34 El Orden, 6/11/1912.

35 Como sostiene LOBATO, op. cit., 2009, p.175, en su análisis sobre las movilizaciones del $1^{\circ}$ de mayo en el Río de la Plata, "los recorridos de las manifestaciones constituían activas demarcaciones territoriales en el espacio urbano". También sobre las manifestaciones obreras en los espacios públicos resultó iluminador el capítulo de LOBATO Y PALERMO, op. cit., 2011, pp. 45-74.

36 El Orden, 28/4/1916.

37 Una muestra en ese sentido en El Orden, 1/5/1916. Propone VIGUERA, op. cit., 1991, p. 60 que el socialismo entendía el $1^{\circ}$ de mayo como una "oportunidad en que los obreros se manifestaban pacífica y legalmente por sus principales reclamos", lo cual le asignaba a la conmemoración un significado festivo, expresado en la misma noción de "fiesta del trabajo", y en la realización de veladas. En contraste, el anarquismo al reconocer el origen de esta efeméride, en primer lugar, "en los hechos de Chicago de 1886 , el $1^{\circ}$ de mayo era entendido entonces como una conmemoración luctuosa, en cuanto debía recordar y homenajear todas las víctimas de la opresión capitalista, y, a la vez una "fecha de rebelión y de protesta" que continuaba el impulso iniciado con aquella huelga". Estos dos significados implicaban el total rechazo al carácter de "fiesta" que, según los anarquistas, buscaban otorgarle a la fecha los socialistas. En una tónica semejante, SURIANO, op. cit., 2001, pp. 319-320 afirma que "el anarquismo demostró siempre una profunda aversión a la concepción festiva y reformista que el socialismo tenía de la jornada e intentó ubicarse en las antípodas". De esta forma, los anarquistas insistieron en el contenido de luto y de protesta que revestía el $1^{\circ}$ de mayo.

38 LOBATO, op. cit., 2009, p. 177. Siguiendo también a Lobato, interesa apuntar que fue el primero de estos sentidos, es decir, el propuesto por el socialismo, el cual, más tarde, retomado y refuncionalizado por otros actores sociales, consiguió mayor durabilidad. En especial, el peronismo revitalizó el sentido de fiesta del $1^{\circ}$ de mayo y le otorgó un carácter monumental a las movilizaciones obreras, tal como lo propone, LOBATO, op. cit., 2009, $p$. 178 y, más recientemente, LOBATO Y PALERMO, op. cit., 2011, p. 59. La construcción del $1^{\circ}$ de mayo peronista es sugerentemente explicada también por VIGUERA, op. cit., 1991, pp. 53-79. Para las manifestaciones del $1^{\circ}$ de mayo en la década de 1930, un trabajo reciente y sugerente es el de RUBINZAL, Mariela Alejandra, !A ganar las calles! Movilizaciones nacionalistas en el periodo de entreguerras, En LOBATO, op. cit., 2011, pp. 137-142. 
39 El Orden, 2/5/1917.

40 El Orden, 2/5/1917.

41 Otra novedad que se manifestó ese mes de mayo de 1919 fue la fundación de la Cooperativa Gremialista Mutua, conformada con capitales de obreros y de empleados destinada a reportar grandes beneficios a las familias, especialmente a las de los hogares pobres. El establecimiento de esta cooperativa "es la demostración mejor de que los trabajadores en general están plenamente convencidos de que de nada vale el pequeño aumento de salario que mediana la acción colectiva y a fuerza de tanto machacar se va consiguiendo de los patrones, si esto está sirviendo de pretexto a los acaparadores e intermediarios para elevar cada día más y en forma inocua los precios de los artículos de consumo" (El Orden, 30/4/1919).

42 HOBSBAWM, op. cit., 2013, p. 136.

43 CATTARUZZA, Alejandro, Historia de la Argentina, 1916-1955. Buenos Aires: Siglo XXI, 2009. Para un panorama de la conflictividad obrera en Tucumán, LANDABURU, Alejandra, "Los industriales y el Departamento Provincial del Trabajo ante el conflicto obrero de 1919 en Tucumán". En LOBATO, Mirta Zaida y SURIANO, Juan (compiladores), La sociedad del trabajo. Las instituciones laborales en la Argentina (1900-1955). Buenos Aires: Edhasa, 2014, pp. 94-96.

44 El Orden, 30/4/1919.

45 El Orden, 3/5/1920.

46 El Orden, 30/5/1921 y 2/5/1921. Un análisis valioso sobre las experiencias asociativas y culturales lideradas por los comunistas en el mundo del trabajo argentino entre 1920 y 1935 es el libro de CAMARERO, Hernán, A la conquista de la clase obrera. Los comunistas y el mundo del trabajo en la Argentina, 1920-1935. Buenos Aires: Siglo XXI, 2007. Sobre la formación del partido Comunista en Argentina, fuerza que surgió tras una escisión entre los socialistas en 1917 que dio lugar a la creación del partido Socialista Internacional en 1918 y pocos años después a su transformación en el partido Comunista, CAMARERO, Socialismo y movimiento sindical: una articulación débil. La COA y sus relaciones con el PS durante la década de 1920. En CAMARERO, Hernán y HERRERA, Carlos Miguel (editores), El partido socialista en Argentina. Sociedad, política e ideas a través de un siglo. Buenos Aires, Prometeo, 2005, p. 191 y BETHELL, Leslie (Ed.), Historia de América Latina. Tomo 7. América Latina: economía y sociedad, 1870-1930. Barcelona: Crítica, 1991, pp. 313-314.

47 El Orden, 30/5/1921 y 2/5/1921.

48 El Orden, 2/5/1922.

49 El 15 de enero de 1923 se sancionó la Ley N 1346 que establecía la Jornada máxima de trabajo --estipulaba la jornada leuegal de trabajo de ocho horas diarias o cuarenta y ocho horas semanales en todo el territorio de la Provincia-- y el 12 de marzo se dictó la Ley $\mathrm{N}^{\circ}$ 1348 de Salario mínimo; ambas leyes fueron promulgadas el 24 de marzo y reglamentadas el 30 de abril de ese año (Ostengo de Ahumada, Ana María (recopilación), La Legislación laboral en Tucumán, Recopilación ordenada de Leyes, decretos y resoluciones sobre derecho del trabajo y seguridad social 1839-1969. T. I, Tucumán: Facultad de Derecho y Ciencias Sociales, Universidad Nacional de Tucumán, 1969, pp. 245-253).

50 LOBATO, op. cit., 2009, pp. 88-89.

51 Ibidem, p. 175.

52 Cumpliendo con la disposición de la Fraternidad, el gremio de los maquinistas y foguistas ferroviarios, los trabajadores pararon ayer durante cinco minutos en homenaje a la lucha 
(El Orden, 1924). Ya habíamos señalado que fue en 1919 cuando se introdujo en Tucumán la costumbre de no laborar ese día, decretando un paro total de actividades. Salvo los trabajadores de ferrocarriles y tranvías que ese año suspendieron sus labores por media hora como tributo a la conmemoración obrera, el resto del mundo del trabajo se plegaba así al paro.

53 Otras actividades organizadas por las avocaciones de trabajadores durante la efeméride fueron, por ejemplo, la conferencia del diputado socialista Agustín Muzzio sobre el tema de la ley de jubilaciones gremiales que tuvo lugar el sábado en el teatro Alberdi con una amplia concurrencia. A su vez, la FORA organizó una manifestación en la plaza Independencia, reuniendo aproximadamente 800 manifestantes que escucharon las palabras sobre el significado social del $1^{\circ}$ de mayo pronunciadas por algunos dirigentes y afiliados de la entidad (El Orden, 1924).

54 Así, por ejemplo, en Brasil durante los años 1920, los socialistas, los anarquistas y los sindicalistas revolucionarios competían por las interpretaciones del primero de mayo, recogiendo, además, las influencias de los sucesos europeos, especialmente a raíz del triunfo revolucionario y la instalación del gobierno obrero en Rusia, como sostiene BILHÃO, op. cit., 2013, pp. 29-52. .

\section{Artigo recebido em abril de 2015. Aceito em junho de 2015.}

